\title{
Multidimensional Use of Pedicled Gluteal Artery Perforator Flaps in Perianal and Gluteal Regions
}

\section{Perianal ve Gluteal Bölge Defektlerinin Onarımında Pediküllü Gluteal Arter Perforatör Flebinin Çok Yönlü Kullanımı}

\author{
Fikret Eren ${ }^{1}$, Sinan Oksuz $^{1}$, Cenk Melikoglu ${ }^{2,{ }^{*}}$, Ahmet Ziya Balta ${ }^{3}$, Ersin Ulkur $^{1}$ \\ ${ }^{1}$ GATA Haydarpasa Training Hospital, Clinic of Plastic Surgery, Istanbul \\ ${ }^{2}$ Department of Plastic Surgery, Faculty of Medicine, Sifa University, Izmir \\ ${ }^{3}$ GATA Haydarpasa Training Hospital, Clinic of General Surgery, Istanbul
}

\begin{abstract}
Objective: Before the concept of the perforator flap, methods such as secondary intention, skin grafting, primary closure, random pattern transposition, and rotation flaps had been used to treat wounds such as pilonidal sinus, hidradenitis suppurativa and pressure sores. In this study the advantages of gluteal artery perforator flaps for the reconstruction of perineal and gluteal region are discussed.
\end{abstract}

Materials and Methods: Between dates August 2011 and August 2014, seventeen patients with perianal and gluteal region defects were operated using gluteal artery perforator flaps. Twenty-five flaps were used, eight of the patients necessitated two flaps. Fifteen of the 25 flaps were SGAP, while nine were IGAP. One patient with trochanteric and ischial pressure sores was reconstructed with $\mathrm{m}$. biceps femoris flap for his trochanteric sore.

Results: Among these 17 patients with gluteal and perineal wounds, eleven had pressure sores, two had hidradenitis suppurativa, two had pilonidal sinus, one had post-burn contracture in the gluteal sulcus and the last one had nevus sebaceous. All flaps survived. The mean follow up period was 11,7 months (range 9-20 months). No early or late complications were evident.

Conclusions: It is our conclusion that the SGAP and IGAP flaps are useful tools for the soft tissue reconstruction of perineal and gluteal region.

Key Words: Gluteal artery, gluteal region defects, perforator flaps, post-burn contracture, perianal region defects, pressure sore

\section{Introduction}

Open and infected wounds of various sizes, such as pilonidal sinus and hidradenitis suppurativa,

\section{ÖZET}

Amaç: Perforator flap konseptinden önce gluteal bölgede plonidal sinüs, hidradenitis suppurativa ve bası yarası rezeksiyonundan sonra oluşan yumuşak doku eksikliklerinin onarımında; sekonder iyileșme, deri greftlemesi, primer onarım, random pattern flepler ve transpozisyon flepleri kullanılmaktaydı. Çalışmamızda gluteal arter perforator fleplerinin perineal ve glueal defektlerin onarımında avantajlarını sunmayı amaçladık.

Gereç ve Yöntem: Ağustos 2011-2014 tarihleri arasında on yedi hasta gluteal arter perforator flebi kullanılarak perineal ve gluteal bölge defektlerinin onarımı için opere edildi. Toplamda 25 flep kullanıldı ve 8 hastaya çift flep ile onarım yapıldi. 15 adet flep SGAP, 9 tanesi IGAP ve bir hastaya da trochanteric bası yarası içi m.biceps femoris flebi kullanıldı.

Bulgular: Gluteal ve perineal yumuşak doku defekti olan 17 hastadan 11 tanesi bası ülseri, 2 tanesi hidradenitis supurativa, 2 adedi plonidal sinus diğer ikisi de intergluteal sulkusta yanık sonrası kontraktür ve sebase nevüs olarak rapor edildi. Tüm flepler başarılı bir şekilde uyguland1, ortalama takip süresi 11,7 ay olarak rapor edildi. Herhangi bir erken veya geç komplikasyonla karşılaşılmadi.

Sonuç: SGAP ve IGAP flepleri özellikle gluteal ve perineal bölge yumuşak doku onarımlarında başarıyla kullanılabilmektedir.

Anahtar Kelimeler: Bası ülseri, Gluteal arter, gluteal bölge defektleri, perforator flep, perianal bölge defektleri, yanık kontraktürü

may occur in the gluteal region. Pressure sore, pilonidal sinus and rarely resection of extensive soft tissue masses result in perianal and gluteal soft tissue defects. Before the concept of the 
Eren ve ark. / Management of Perianal and Gluteal Region Defects

Table 1. Patients repaired with 'gluteal artery' perforator flaps

\begin{tabular}{|c|c|c|c|c|c|}
\hline Patient & Age/sex & Diagnosis & Location of morbidity & $\begin{array}{ll}\text { pattern } & \text { of } \\
\text { pedicle/ flap }\end{array}$ & $\begin{array}{l}\text { Follow-up } \\
\text { period }\end{array}$ \\
\hline 1. Fig.1a-b & $53 / f$ & $\begin{array}{l}\text { Post-burn } \\
\text { contracture }\end{array}$ & Sulcus interglutealis & SGAP & 19 months \\
\hline \multirow[t]{2}{*}{ 2.Fig.2a-b } & \multirow[t]{2}{*}{$60 / \mathrm{m}$} & \multirow[t]{2}{*}{ Pressure sore } & Sacral & SGAP & \multirow{2}{*}{10 months } \\
\hline & & & Ischial & IGAP & \\
\hline 3. Fig.3a-b & $20 / \mathrm{m}$ & Pressure sore & Sacral & IGAP & 10 months \\
\hline 4. Fig. $4 a-b$ & $21 / \mathrm{m}$ & Nevus sebaceous & Perianal & SGAP & 14 months \\
\hline 5. Fig.5a-b & $21 / \mathrm{m}$ & Pilonidal sinus & Sacral & SGAP & 16 months \\
\hline \multirow{2}{*}{$\begin{array}{l}\text { 6. Fig.6a-b- } \\
\text { c-d }\end{array}$} & \multirow{2}{*}{$52 / \mathrm{m}$} & \multirow{2}{*}{ Pressure sore } & Trochanteric & m. biceps femoris & \multirow[t]{2}{*}{19 months } \\
\hline & & & Ischial & IGAP & \\
\hline 7. Fig. 7a-b-c & $23 / \mathrm{m}$ & $\begin{array}{l}\text { Hidradenitis } \\
\text { suppurativa }\end{array}$ & Gluteal region (Grade-3) & SGAP & 8 months \\
\hline 8. & $75 / \mathrm{m}$ & Pressure sore & Sacral & SGAP & 10 months \\
\hline 9. & $18 / \mathrm{m}$ & Pressure sore & Sacral & SGAP (bilateral) & 10 Months \\
\hline 10. & $22 / \mathrm{m}$ & Pilonidal sinus & Sacral & SGAP (bilateral) & 9 months \\
\hline \multirow[t]{2}{*}{11.} & \multirow[t]{2}{*}{$62 / \mathrm{m}$} & \multirow[t]{2}{*}{ Pressure sore } & Trochanteric & IGAP & \multirow{2}{*}{11 months } \\
\hline & & & Ischial & IGAP & \\
\hline 12. & $65 / \mathrm{m}$ & Pressure sore & Sacral & SGAP (bilateral) & 8 months \\
\hline 13. & $22 / \mathrm{m}$ & Pressure sore & Ischial & IGAP & 10 months \\
\hline 14. & $24 / \mathrm{m}$ & Pressure sore & Trochanteric & IGAP & 7 months \\
\hline 15. & $67 / \mathrm{m}$ & Pressure sore & Sacral & SGAP (bilateral) & 10 months \\
\hline 16. & $65 / \mathrm{m}$ & Pressure sore & Trochanteric & IGAP & 8 months \\
\hline 17. & $21 / \mathrm{m}$ & $\begin{array}{l}\text { Hidradenitis } \\
\text { suppurativa }\end{array}$ & Gluteal region (Grade-3) & SGAP & 20 Months \\
\hline
\end{tabular}

perforator flap, methods such as secondary intention, skin grafting, primary closure, random pattern transposition, and rotation flaps had been used to treat these wounds $(1,2)$. Each of these methods has its particular limitations (3).

Long pedicles of superior and inferior gluteal artery perforator flaps facilitate mobilization of neighbouring healthy tissue into the defect area (4). Another advantage is the abundant amount of sizable perforators belonging to the superior and inferior gluteal arteries. This condition makes possible the planning of various sizes and shapes of flaps around the defect area.

We aim to present our clinical experiences in using superior and inferior gluteal artery perforator flaps in gluteal region defects for various reasons.

\section{Materials and Methods}

Patients treated in our clinic with soft tissue defects in the gluteal regions due to pilonidal sinus, pressure sore and hidradenitis between dates August 2011 and August 2014, were included in the study. One patient was operated for neurofibroma. Before the operation, perforators were determined by using the manual $8 \mathrm{MHz}$ hand held Doppler. Enema was administered prior to surgery. The procedure was performed under spinal anesthesia in all patients. With the flap planned to be approximately the size of the area of the defect in the region where perforators were marked, local anesthesia was inducted at incision borders. The wound area was excised radically until healthy subcutaneous tissue was reached. An SGAP or IGAP flap containing perforators was planned adjacent to the defect area. Incision was started at the near border of the wound area. The flap was elevated in the subfascial plane while preserving the perforators previously marked by the manual Doppler. The subfascial plane was a safe level for identifying the perforators, and to dissect them precisely. Localization of the perforators during dissection was made easier by translumination at set intervals 
while coursing parallel to muscle fibers. During the postoperative period, clear diet and oral diphenoxylate and atropine were administered for 3 days in order to prevent fecal contamination. Patients received first generation cephalosporins intraoperatively and postoperatively, and the drug was stopped on the fifth postoperative day. When the outflow was below $30 \mathrm{ml} /$ day, the drainage was removed. Consultations to recommend general surgery were conducted with two patients with perianal region excision. All patients were operated by the same surgeons. Eleven patients had pressure sores, two had hidradenitis suppurativa, two had pilonidal sinus, one had post-burn contracture in the gluteal sulcus and the last one had nevus sebaceous (Table 1).

\section{Results}

A total of 17 patients were operated because of wounds in the perianal and gluteal regions. All patients were male except one. The age of the patients ranged between 20 and 75 years (mean of 40,7 years). After the excision, lesion dimensions were between $5 \times 6 \mathrm{~cm}$ and $18 \times 27 \mathrm{~cm}$ (mean of
$12 \times 17 \mathrm{~cm})$. A total of 25 flaps were performed on 17 patients; nine of these were IGAP, fifteen were SGAP and one was a biceps femoris muscle transposition flap. Eight patients were treated by double flaps. The mean duration of the procedure was 1.5 hours, and mean duration of follow up was 11.7 (8-20) months.

Case 1: A 50-year-old ambulatory female patient presented with a 35-year history of intergluteal post-burn contracture following a flame induced thermal injury. A SGAP flap was used to cover the intergluteal defect caused by contracture release. The donor site was closed primarily. The flap healed uneventfully. The follow-up period was 19 months. No contracture recurrence was observed (Figure 1).

Case 2: A 60-year-old male patient had a Grade 3 sacral and ischial pressure sores for 10 months. The sacral defect was $8 \times 8 \mathrm{~cm}^{2}$ and the ischial was $10 \times 10 \mathrm{~cm}^{2}$ after debriding the necrotic tissue. SGAP and IGAP were raised to cover the defects. At his latest follow-up 10 months later, flap recovery was successful and no recurrence was noted (Figure 2).

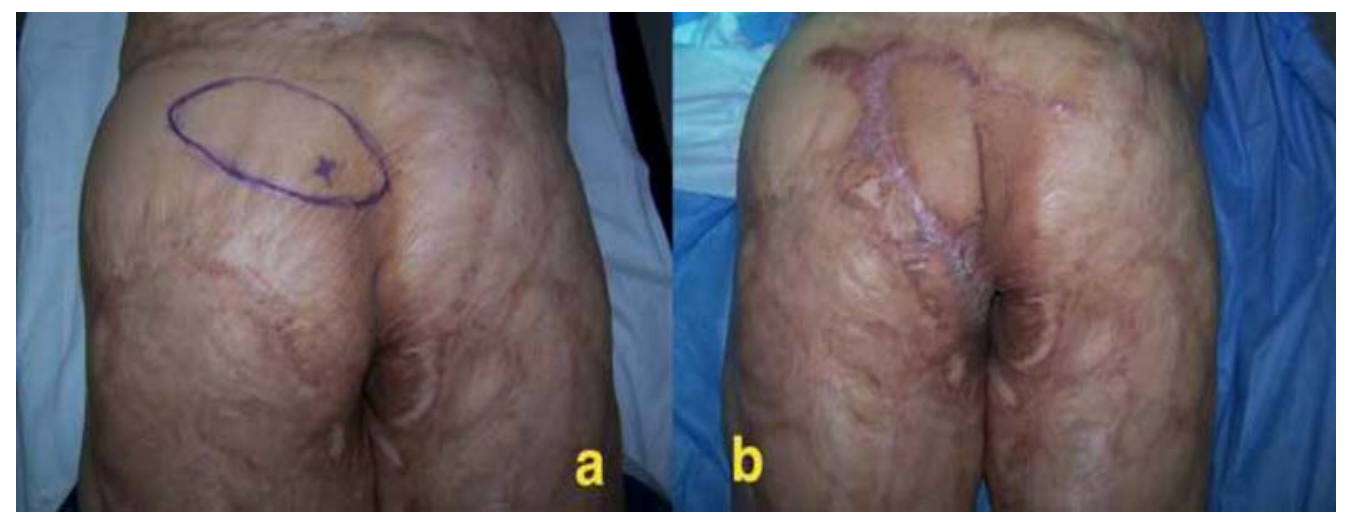

Figure 1a). Preoperative view of the patient, b). 19. month post-operative view of the patient.

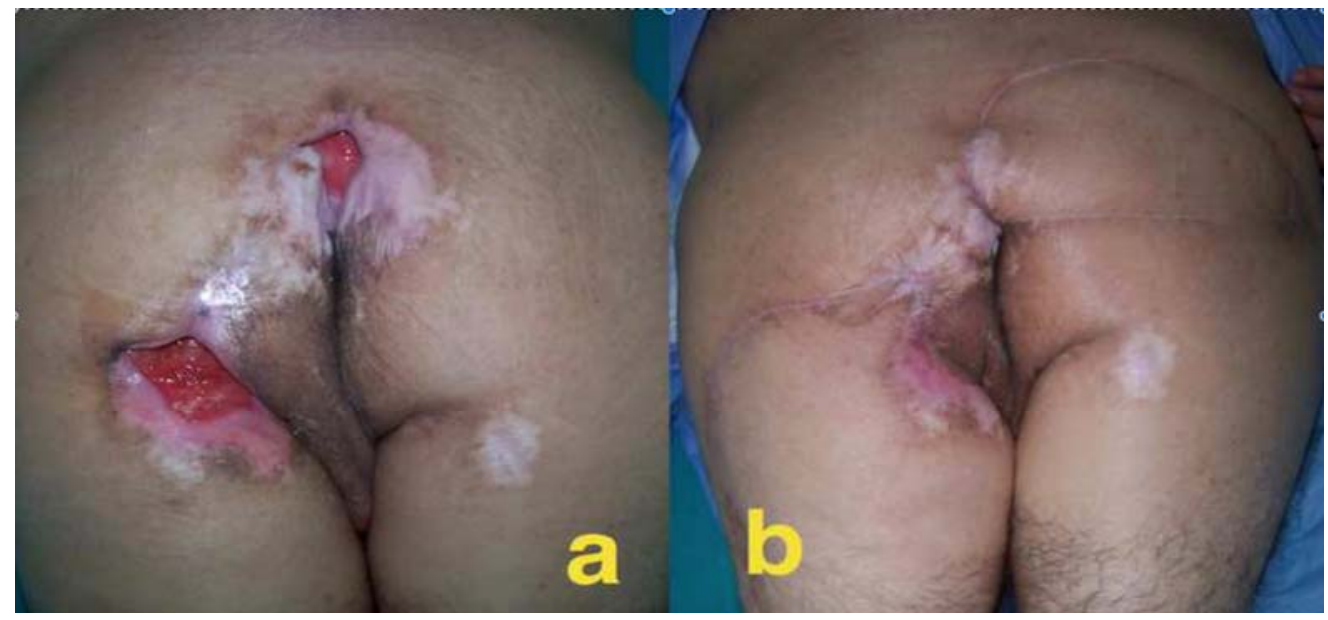

Figure 2a). Preoperative view of the patient. b). 10. Month post-operative view. 
Eren ve ark. / Management of Perianal and Gluteal Region Defects

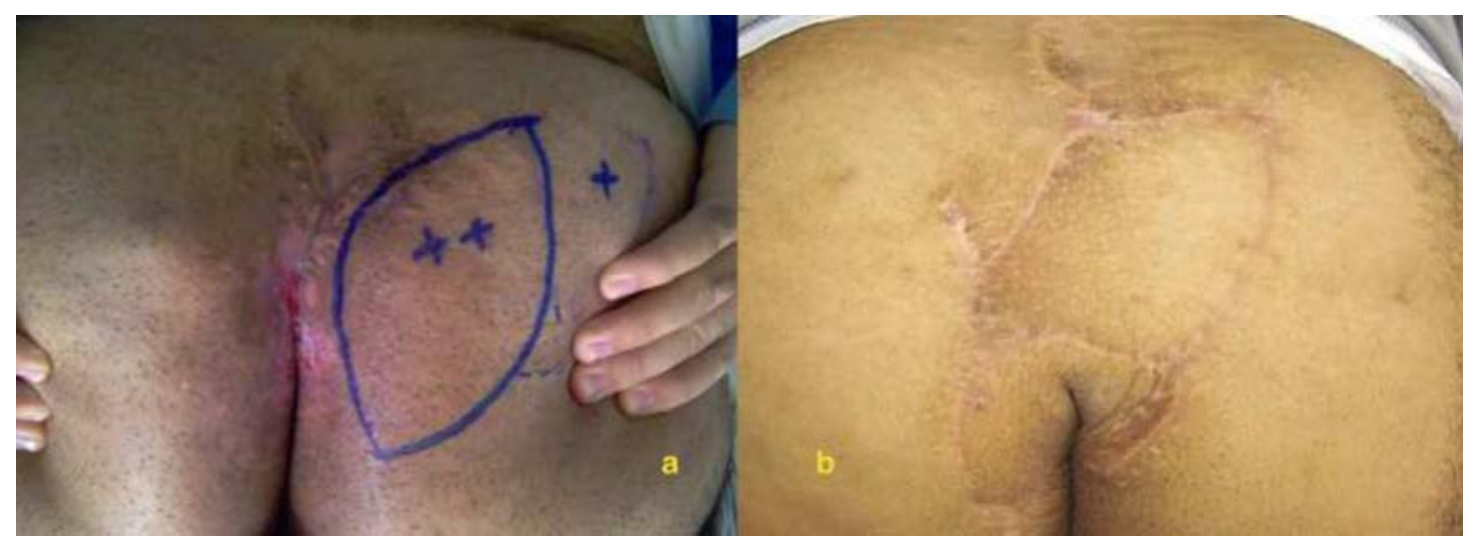

Figure 3a). Preoperative view of the patient. b). 10th month post-operative view of the patient.

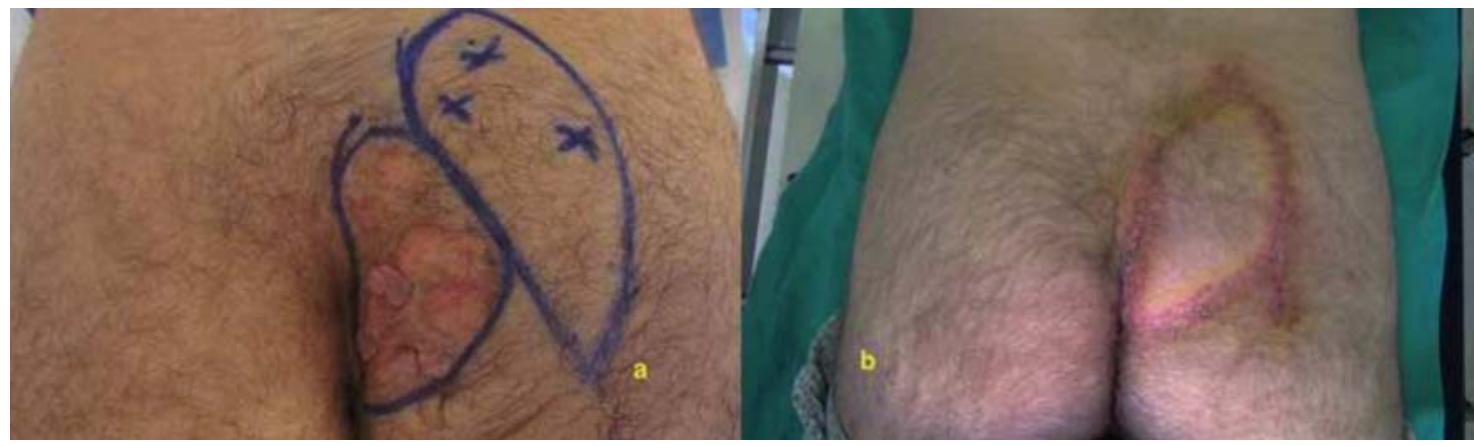

Figure 4a). Preoperative view of the nevus sebaceous on the right gluteal region. b). Postoperative view of the patient.
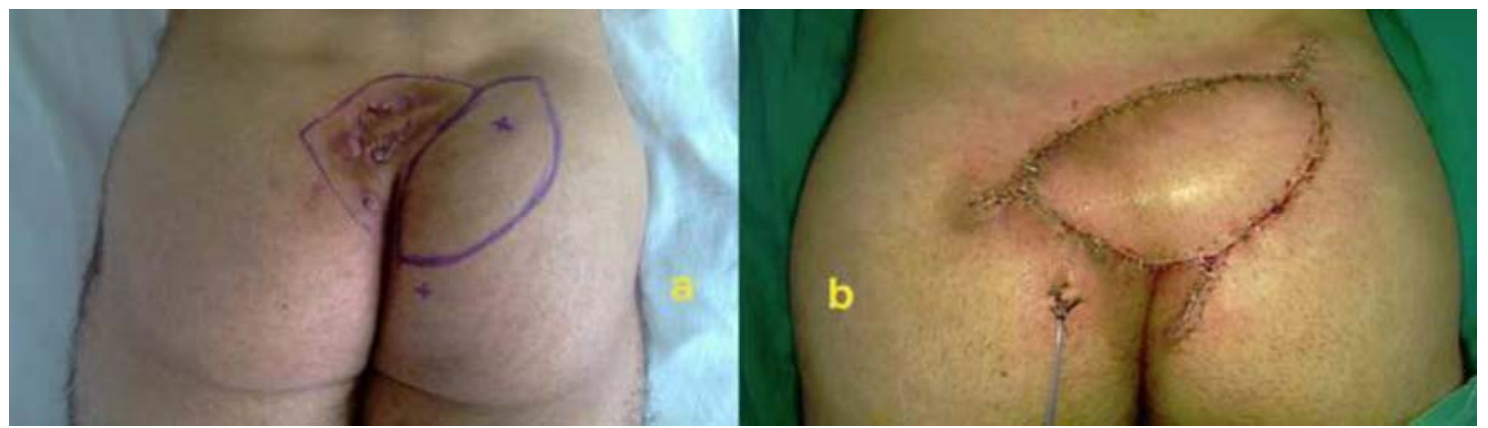

Figure 5a). Preoperative view of the patient. b). Early post-operative view of the patient.

Case 3: A 20-year-old ambulatory male patient was referred with grade 3 pressure sore on his sacral region. Under spinal anesthesia the lesion was totally excised and the soft tissue defect was closed with IGAP flap. The donor site was closed primarily. The follow-up period was 10 months and flap recovery was unproblematic (Figure 3).

\section{Discussion}

Pedicled SGAP and IGAP flaps are quite useful in the repair of gluteal region defects. Previously, some problems have been encountered in defects closed by secondary intention, grafting, or random pattern local flaps. Scarred appearance and sensitivity caused by friction from underwear are long-term morbidities. Healing may take a long time in large defects, and it can be also psychologically exhausting. Grafting is also an option for wound closure. However, this is difficult in a region where humidity is high due to lymphatic drainage or perspiration. To overcome this problem, performing the holes on the graft increases the success rate of the grafting, but it will cause a cosmetically unpleasant appearance. After the graft take a distinct shape, cosmetic deformities such as the depression of the grafted area in the gluteal region, color difference, and patchy appearance are commonly encountered. Local flaps such as rotation or transposition flaps are commonly employed options for wound closures in this region. These flaps, which are 


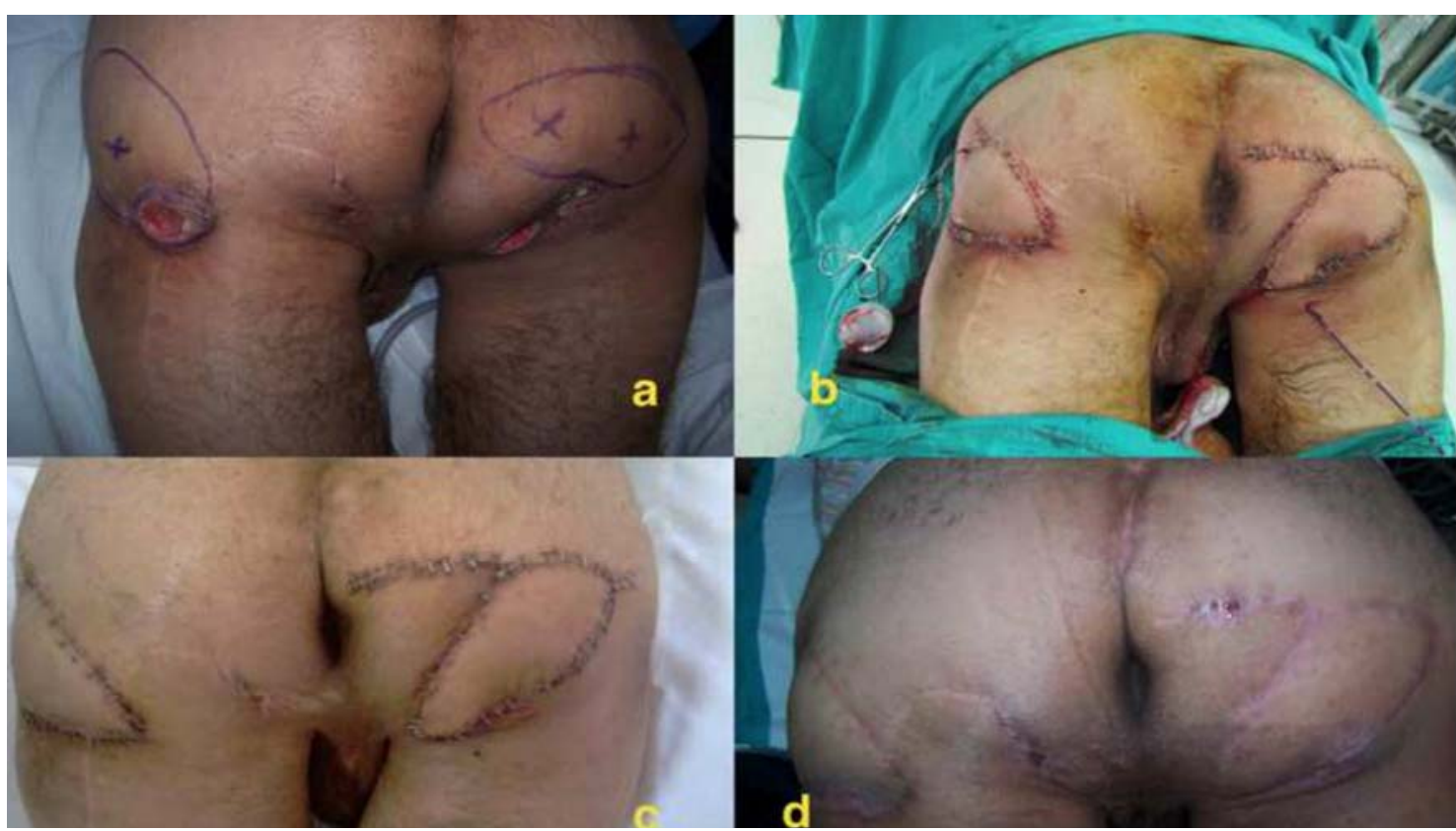

Figure 6a). Preoperative view of the patient. b). Intraoperative view of the patient. c). 10th day post-operative view of the patient. d). 19th month post-operative view of the patient.

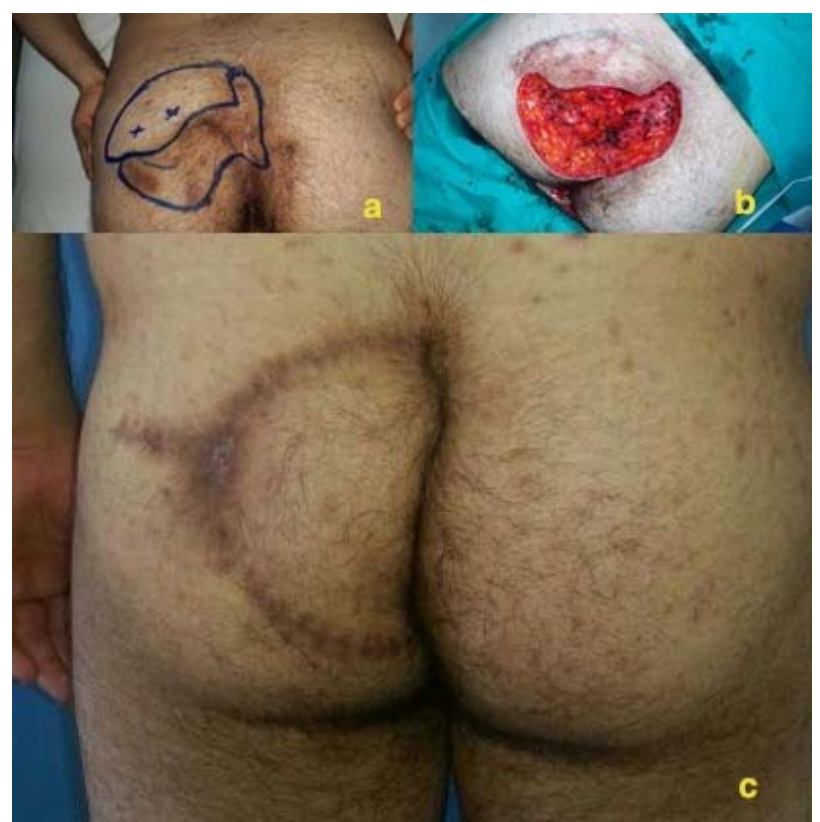

Figure 7a). Preoperative view of the patient. b). Early view after excision of the lesion. c). 8th month postoperative view of the patient.

elevated in random patterns, can be planned as large as the width-length ratio enables. Therefore, their usage in large defects is limited, or usually more than one flap is required. On the other hand, after they are placed on the defect, tension pockets may be formed, and they may cause borderline deformities. Partial necrosis and dehiscence are commonly encountered complications in these flaps. The gluteus maximus myocutaneous flap has also been widely used for reconstructing sacral and gluteal pressure sores $(5,6)$. However disadvantages such as limited flap rotation and sacrificing the muscle may limit the application. After the perforator concept, we think that the SGAP and IGAP flap methods we have used are very useful and practical in repairs of gluteal region defects (7).

In all cases, SGAP and IGAP were skeletalized to the segmentary artery. This skeletalization greatly increased flap mobilization. However, small diameter venous insufficiency may be encountered in addition to risk of pedicle damage in this condition. Perforator flaps offer a new approach in microsurgical soft tissue repair. A perforator vessel is an arterial branch that has its origin in one of the axial arteries together with its venous component and passes through the deep fascia and forms the subcutaneous vascular plexus. These flaps are able to move in almost all directions so that they can be designed in large dimensions (8). Major advantages of perforator flap over the myocutaneous flap include reduced bleeding, preserving the underlying muscle and increased arc of rotation of the flap. Bilateral weakness of the M. Gluteus maximus muscle may cause loss of walking activity and necessitates the aid of crutches. However, disadvantage of perforator and propeller perforator flaps is mostly the insensate nature of the flaps. Most insensate 
local flaps may develop a slight sensory recover via peripheral innervations. In addition to this condition a myocutaneous flap is still a better choice for filling an extensive cavity when more bulk tissue is indicated $(9,10)$. The SGAP and IGAP flaps provide large bulky and save skinsubcutaneous flap to manage perineal and gluteal soft tissue defects. $(10,11)$. There were no recurrences in the patient cases during the followup period.

Pedicled gluteal artery perforator flaps are quite useful in the repair of wounds in the gluteal region caused by any reason such as a pressure ulcer, pilonidal sinus or hidradenitis. In particular, adequately large excision of pilonidal sinuses without any concern about the closure will reduce the recurrence risk to a great extent.

The gluteal artery perforator flaps provide safe skin-subcutaneous flaps to cover perineal defects with no muscle function loss. Usage of this flap provides tension-free skin closure, and also reduces the risk of local recurrence. They can be considered as a first-line option. This contributes to the preservation of muscle flaps for later procedures to treat commonly encountered wounds in this region, such as pressure ulcers.

\section{References}

1. Mancoll JS, Philips LG. pressure sores. In: Aston SJ, Beasly RW, Thorne CHM, editors. Grabb and Smiths's plastic surgery, 5 th ed. New York: Lippincot-Raven: 1997: 1083-1097.

2. Mathes SJ, Nahai F. Reconstructive surgery: principals, anatomy, and technique. New York: Churchill Livinhstone; 1997: 499-535.
3. Kishi $\mathrm{K}$, Nakajima H, Imanishi N. Reconstruction of skin defects after resection of severe gluteal hidradenitis suppurativa with fasciocutaneous flaps. J Plast Reconstr Aesthet Surg 2009; 62(6): 800-805.

4. Ahmadzadeh R, Bergeron L, Tang M, Morris S. The superior and inferior gluteal artery perforators. Plast Reconstr Surg 2007; 120(6): 1551-1556.

5. Ger R. The surgical management of decubitus ulcers by muscle transposition. Surgery 1971; 69(1): 106-110.

6. Yamamoto Y, Tsutsumida A, Murazumi M, Sugihara T. Long-term outcome of pressure sores treated with flap coverage. Plast Reconstr Surg 1997; 100(5): 1212-1217.

7. Unal C, Yirmibesoglu OA, Ozdemir C, Hasdemir M. Superior and inferior gluteal artery perforator flaps in reconstruction of gluteal and perianal/perineal hidradenitis suppurativa lesions. Microsurgery 2011; 31(7): 539-544.

8. Ozmen S, Kandal S, Findikcioglu F, Mentes B. Superior gluteal artery perforator flap: an alternative in the treatment of complicated pilonidal sinus. Gazi Medical Journal 2006; 3(17): 176-178.

9. Kendall FP, Mc Creary EK, Provance P. Gluteus maximus. In muscle testing and function. 4th ed. Baltimore: Williams and Wilkins; 1993.

10. Korambayil PM, Allalasundaram K, Balakrishnan T. Perforator propeller flaps for sacral and ischial soft tissue reconstruction. Indian J Plast Surg 2010; 43(2): 151-157.

11. Higgins JP, Orlando GS, Blondeel PN. Ischial pressure sore reconstruction using an inferior gluteal artery perforator. Br J Plast Surg 2002; 55(1): 83-85. 